\title{
The impact of the flipped classroom on receptive and productive vocabulary learning
}

\author{
ÖzkanKırmızi ${ }^{\text {a* (D) }}$, FundaKömeç \\ ${ }^{a}$ Karabük University, Karabük, Turkey \\ ${ }^{b}$ Mehmet Vergili Science High School, Karabük, Turkey
}

APA Citation:

Kırmızı, Ö., \&Kömeç, F. (2019). The impact of the flipped classroom on receptive and productive vocabulary learning. Journal of Language and Linguistic Studies, 15(2), 437-449.

Submission Date:25/10/2018

Acceptance Date:21/11/2018

\begin{abstract}
The aim of the present study was to measure the effect of the flipped classroom on vocabulary learning in terms of both receptive and productive vocabulary. To do this, a post-test experimental research design was implemented. The participants of the study are 58 high school students. The experimental group was exposed to a four-week flipped instruction in which they worked on the pre-prepared videos designed by the teacher. The practice was done collaboratively inside the classroom. The control group was taught the target vocabulary in the traditional way in which the vocabulary presentation took place in the classroom and the practice was done as homework. Following the instruction of each group of words, a vocabulary quiz was administered to both groups. The results were analyzed by using the SPSS package program. The experimental group's perceptions of the flipped classroom were also evaluated through an open-ended questionnaire. Depending on the results, it can be stated that the flipped classroom holds promise for the language learning process in terms of vocabulary learning.
\end{abstract}

C 2019JLLS and the Authors - Published by JLLS.

Keywords:Flipped classroom; receptive vocabulary; productive vocabulary

\section{Introduction}

Words are the building blocks of language. They form the foundation upon which all language skills are built.As Milton (2013) argues "the more vocabulary learners know, the better they are likely to perform through the medium of the foreign language". Therefore, one of the primary tasks of a language teacher is to help students acquire and retain vocabulary. Nation (2001) argues that vocabulary must be deliberately taught foreign language learners. He suggests providing learners with "multiple and various exposures to a word before they fully understand that word and can apply it". With "understanding and applying a word", Nation (2001) refers to two different degrees of control that learners have over their vocabulary knowledge: receptive and productive knowledge. This is a widely accepted distinction that researchers use when investigating vocabulary acquisition (Shahov, 2012). While extracting meaning from what one hears or reads comprises receptive knowledge, productive knowledge refers to using words appropriately to express oneself. It is often the case that one has a larger receptive vocabulary

\footnotetext{
${ }^{*}$ Corresponding author. Tel.: +506 5339044
}

E-mail address: ozkankirmizi@gmail.com 
than a productive vocabulary. It is also easier to acquire a receptive control of words than a productive control, which often develops later.

Traditionally, vocabulary is taught in three modes of instruction: visual, verbal and translation (Gairns and Redman, 1986). Visual techniques involve using flashcards, realia, drawings, mime or gestures. These are useful in introducing words related to real objects and descriptions of people or places. Verbal methods refer to giving definitions, synonyms and antonyms of words as well as examples. These are especially helpful in teaching abstract words. Translation method works well with low frequency words and helps save time. The main drawback of the traditional methods is that they are all teacher-centered. They require a rather passive involvement of learners, who are likely to lose motivation and interest over time when taught only with these methods (Zhang et al, 2016). Due to time constraints, application of the target vocabulary is almost non-existent in most traditional language classrooms. Students are usually encouraged to memorize without ever using the new words communicatively or productively.

While traditional methods of teaching vocabulary develop mostly the receptive vocabulary knowledge, recent approaches favor more active involvement with words to improve students' productive vocabulary knowledge, as well. In most language classrooms in Turkey, vocabulary is mostly taught through traditional methods. Since the vocabulary level of our students is far from satisfying, this passive way of teaching needs restructuring.

It is essential, then, to find more effective ways of teaching our students vocabulary. Rather than simply giving them word lists to memorize, we had better involve them in vocabulary learning in a more autonomous and dynamic mode. We can assign our students a variety of digital resources that present the target vocabulary in meaningful and enjoyable contexts. They can go over these materials before coming to class. In the classroom, theycan engage in communicative tasksand use the target vocabulary actively. We, as teachers, monitor their performance during this stage and offer assistance when necessary. This, in fact,is a recent approach to teaching which is known as "the flipped classroom".

The "flipped classroom" was pioneered and popularized by two American teachers, Aaron Sams and John Bergmann. In their book "Flip Your Classroom: Reach Every Student in Every Class Every Day" (Bergmann \&Sams, 2012), Bergmann and Sams describe a flipped classroom as a setting where that "which is traditionally done in class is now done at home, and that which is traditionally done as homework is now completed in class" (p. 13). The model offers a solution to the time constraints of active learning. It deals with content delivery through multimedia resources or written materials outside the class and frees teachers and students for dynamic activities in the classroom. Knowledge and comprehension, the lowest levels of Bloom's Taxonomy, are taken care of in students' own time. This way it also ensures personalization of learning as well as autonomy. Students take responsibility for their own learning at their own pace.

Recently, learner-centered methods that allow for active learning have been favored over teachercentered methods in foreign language pedagogy. Teachers are expected to create a learning environment where learners interact with the material as well as with each other to construct meaning (Richards, 2006).As for vocabulary instruction, learners are encouraged to learn autonomously and are assigned collaborative tasks that involve application of target words communicatively. In this method, the role of the teacher is that of a facilitator who guides students through the learning process. The main drawback of these methods is that they are time-consuming. Class time is usually insufficient for group work and pair work especially in crowded classrooms. Besides, most students lack the motivation and the resources needed to learn autonomously.

This is where the flipped classroom proves beneficial to both teachers and learners. It provides both the learning resources and the time needed for communicative activities in the classroom. The method 
involves presenting target vocabulary items in videos that address both visual and auditory learning styles. Thus, it helps teachers deal with content delivery outside the classroom and allocatethe class time for hands-on activities. Students are assigned to watch the videos prior to lessons and come to class prepared. This way they take on responsibilities and learn autonomously. Moreover, learning of the new vocabulary is consolidated through collaborative tasks in the classroom. Flipped learning is advantageous from a motivational standpoint, too. Studies have found that integration of technology into education enhance students' motivation for learning (Baz, 2016; Murdoch and Williams, 2011; Liu, 2009).

\subsection{Literature review / Theoretical Background}

Research shows that learning environments are most effective when they elicit effortful, cognitive processing from learners and guide them in actively constructing meaningful relationships rather than encouraging passive recording and storage of information (Craik \&Tulving, 1975; Wittrock, 1992; Lynch 2016).By adopting the flipped method we can incorporate active learning into our teaching and enable students to retain vocabulary longer and use it in a productive way.

Researchers worldwide have looked into the effects of flipped method in teaching English as a foreign language.While its efficacy in student achievement, engagement and satisfaction has been demonstrated in these studies, some challenges, such as the difficulties students experience in adjusting to active learning, have also been reported in the literature.

Zhang et al. (2016) carried out a study into the adjustment and effects of vocabulary teaching strategies in a flipped classroom. They compared vocabulary teaching in a flipped classroom with vocabulary teaching in a traditional classroom. The participants were the freshmen English majors of the foreign languages department of a university in China. After the instruction period, students in both classrooms were given a test of target vocabulary items. Students in the flipped classroom got better test scores than those in the traditional classroom. Besides the test, students from both classrooms were interviewed about different aspects of the learning situations and their attitudes toward each method. The students in the flipped classroom said they could learn the vocabulary before class by the video and get clarification about the problematic areas from the teacher or other students in class discussions. They thought the in-class activities helped them master the new vocabulary in an engaging way. The students in the traditional classroom, on the other hand, found the teacher's explanations about the words boring and time-consuming, and they reported they could not remember most of the words taught. The researchers concluded that flipped instruction improved students' interest in vocabulary learning and enhanced their language output.

Başal (2015) investigated the perceptions of prospective English language teachers at a state university in Turkey on flipped classrooms. After two semesters of flipped instruction in advanced reading and writing classrooms, participants were asked to report the benefits of video lectures. The content analysis of the responses showed that pre-service English teachers had positive attitudes towards the use of the flipped classroom as an integral part of face-to-face courses. He concluded that flipped classroom was beneficial in terms of four categories: learning at one's own pace, advance student preparation, overcoming the limitations of class time and increasing the participation in the classroom.

Alsowat (2016) sought to explore the effect of a suggested EFL Flipped Classroom Teaching Model on graduate students' English higher-order thinking skills, engagement and satisfaction. The data analysis revealed that flipped model was effective in increasing students' foreign language higher order thinking skills, engagement and satisfaction. In another study, Hung (2014) sought to investigate the effectiveness of the integration of flipped teaching using a WebQuest active learning strategy in terms of English language learners' academic performance, learning attitudes, and participation levels. This 
study found that the structured and semi-structured flip lessons were more effective instructional designs than the non-flip lessons.

Roth and Suppasetseree (2016) focused on the effects of flipped classroom on learners' listening comprehension. Applying both quantitative and qualitative methods, they explored the effectiveness of the flipped classroom in enhancing Cambodian pre-university students' English listening skills and investigated the students' opinions on the flipped classroom to enhance English listening comprehension. The results indicated that the flipped classroom enhances Cambodian pre-university students' English listening skills. In the questionnaire and semi-structured interviews, students expressed positive views on learning English through flipped classroom.

As can be seen, the literature provides a lot of insight into the application of the flipped method for teaching English in higher education. However, as is indicated by Mehring (2016), it barely offers any research on flipped English classrooms in secondary education institutions. In this study, we are looking into the effects of the flipped method on vocabulary teaching in a high school inTurkey. We are interested in high school students' proficiency in receptive and productive vocabulary when taught through the flipped method. Is the flipped method more effective than the traditional method? The answer is important since a good command of vocabulary underlies overall language proficiency.

\subsection{Research questions}

In this study we set out to implement the flipped method to teach $10^{\text {th }}$ grade students English vocabulary. The study aims to find out the differences between teaching vocabulary through the flipped classroom and through the traditional classroom. The questions that guide our study are as follows:

(1) Are there significant differences between the control group and the experimental group in terms of average grades in the four quizzes administered?

(2) Are there significant differences between the control group and the experimental group in terms of productive and receptive knowledge of vocabulary tested in the quizzes?

(3) What are the students' attitudes towards flipped classroom in terms of classroom performance?

(4) What are the students' perceptions of the development of their language skills in a flipped classroom?

(5) What are the students' attitudes towards flipped classroom in terms of satisfaction?

\section{Method}

\subsection{Sample / Participants}

The participants of our study are 58 tenth grade students in a science high school in Karabük, Turkey. The students had three lessons of English a week. At the beginning of our study, they were given a placement test to determine their level of English and ensure an equal distribution between the experimental and the control group. 
Table 1. The participants' profile

\begin{tabular}{lll}
\hline & Experimental Group & Control Group \\
\hline Grade & $10^{\text {th }}$ & $10^{\text {th }}$ \\
Level of English & A2 & A2 \\
Female & 18 & 17 \\
Male & 11 & 12 \\
Total number & 29 & 29 \\
\hline
\end{tabular}

\subsection{Instrument( $s)$}

After each session of flipped and traditional teaching, both groups of students were given quizzes testing the target vocabulary. The quizzes included questions measuring both receptive and productive knowledge of words. At the end of the four-week period, the experimental group was given a five-item open-ended questionnaire to get their views related to their flipped classroom experience.

\subsection{Data collection procedures}

The experimental group received flipped instruction and the control group was taught with the traditional method for four weeks.The vocabulary areas taught are as follows:

Types of TV programs (Week 1)

Environment (Week 2)

Travel (Week 3)

\section{Adjectives (Week 4)}

Each week the experimental group was assigned a video presenting the vocabulary based on the $10^{\text {th }}$ grade English curriculum. The video demonstrated the meanings of the words with visuals and plenty of examples in appropriate contexts. The voice-over in the video showed how to pronounce the words as well. In the classroom, the lesson started with a round-up of the vocabulary presented in the video. The teacher used a quick game for the round-up. After that, the students were asked to do vocabulary exercises in pairs or groups. The teacher monitored the pairs / groups and assisted them when necessary. In the next lesson, the students were given a quiz that assessed the target vocabulary of the week.

The control group was presented the target vocabulary inside the classroom. The teacher explained each word using visuals and example sentences. She also asked them to repeat the words after her as pronunciation work. Students took notes and the lesson was over. They were assigned vocabulary exercises as homework. In the next lesson, the students were given a quiz that assessed the target vocabulary of the week.

Table 2. The flipped classroom paradigm

\begin{tabular}{ll}
\hline Before (outside) class & Inside class \\
\hline Video lectures & Question-Answer round-up \\
Note taking & $\begin{array}{l}\text { Practice exercises } \\
\text { (cloze test, picture story) }\end{array}$ \\
\hline & Quiz \\
\hline
\end{tabular}


Table 3. The traditional classroom paradigm

\begin{tabular}{ll}
\hline Inside class & After (outside) class \\
\hline Lectures & $\begin{array}{l}\text { Practice exercises } \\
\text { (cloze test, picture story) }\end{array}$ \\
\hline Quiz & \\
\hline
\end{tabular}

\subsection{Data analysis}

The quizzes of the experimental group and the control groupwere analyzed quantitatively using the Statistical Package for Social Sciences (SPSS). The open-ended responses to the questionnaire were coded into categories and thus analyzed.

\section{Results}

The findings are presented in the tables below. Table 4 presents the independent samples t-test comparing the scores of the experimental group and the control group in terms of receptive and productive vocabulary tasks and the average grade for Quiz 1.

Table 4. Independent samples t-test for Quiz 1

\begin{tabular}{ccccccc}
\hline Quiz 1 & Group & $\mathrm{n}$ & $\mathrm{M}$ & $\mathrm{SD}$ & $\mathrm{t}$ & $\mathrm{p}$ \\
\hline ProductiveVocabulary & Control & 24 & 15.6250 & 4.33201 & -.881 & .383 \\
& Experimental & 28 & 16.5357 & 3.09698 & -.859 & .395 \\
ReceptiveVocabulary & Control & 24 & 57.1250 & 13.01943 & -.299 & .766 \\
& Experimental & 28 & 58.2143 & 13.15254 & -.299 & .766 \\
Grade average & Control & 24 & 72.7500 & 15.38845 & -.488 & .627 \\
& Experimental & 28 & 74.7500 & 14.13329 & -.485 & .630 \\
\hline
\end{tabular}

The data in table 4 above show no statistically significant differences between the control group, who received traditional vocabulary instruction, and the experimental group, who received flipped vocabulary instruction ( $\mathrm{p}>.05)$.

Table 5 below presents the independent samples t-test comparing the scores of the experimental group and the control group in terms of receptive and productive vocabulary tasks and the average grade for Quiz 2.

Table 5. Independent samples t-test for Quiz 2

\begin{tabular}{ccccccc}
\hline Quiz 2 & Group & $\mathrm{n}$ & $\mathrm{M}$ & $\mathrm{SD}$ & $\mathrm{t}$ & $\mathrm{p}$ \\
\hline Productive & Control & 29 & 54.4483 & 8.00708 & -1.558 & .125 \\
Vocabulary & Experimental & 28 & 57.3214 & 5.67028 & -1.568 & .123 \\
Receptive & Control & 29 & 37.1724 & 5.35903 & -2.004 & .050 \\
Vocabulary & Experimental & 28 & 39.5000 & 3.06111 & -2.022 & .049 \\
Grade average & Control & 29 & 91.6207 & 12.70662 & -1.893 & .064 \\
& Experimental & 28 & 96.8214 & 7.17534 & -1.911 & .062 \\
\hline
\end{tabular}


According to the results, there are no statistically significant differences between the control and experimental group in terms of productive vocabulary and the grade average in the second quiz ( $p>.05$ ). However, the results indicate a significant difference between the control group and the experimental group in terms of receptive vocabulary $(\mathrm{p}<0.05)$. We can understand from means scores that the experimental group $(M=39.5000)$ performed better than the control group $(M=37.1724)$ in terms of receptive vocabulary.

Table 6 shows the independent samples t-test comparing the scores of the experimental group and the control group in terms of receptive and productive vocabulary tasks and the average grade for Quiz 3 .

Table 6. Independent samples t-test for Quiz 3

\begin{tabular}{ccccccc}
\hline Quiz 3 & Group & $\mathrm{n}$ & $\mathrm{M}$ & $\mathrm{SD}$ & $\mathrm{t}$ & $\mathrm{p}$ \\
\hline Productive & Control & 27 & 31.5556 & 10.66025 & -.984 & .330 \\
Vocabulary & Experimental & 29 & 34.2069 & 9.50706 & -.980 & .332 \\
Receptive & Control & 27 & 38.2963 & 11.91900 & 1.851 & .070 \\
Vocabulary & Experimental & 29 & 32.4138 & 11.84880 & 1.851 & .070 \\
Grade average & Control & 27 & 69.8519 & 20.75184 & .607 & .546 \\
& Experimental & 29 & 66.6207 & 19.04208 & .606 & .546 \\
\hline
\end{tabular}

According to the t-test, the control group and the experimental group do not significantly differ in terms of productive and receptive vocabulary as well as overall grade average in the third quiz ( $p>.05)$.

Table 7 presents the independent samples t-test comparing the scores of the experimental group and the control group in terms of receptive and productive vocabulary tasks and the average grade for Quiz 4.

Table 7. Independent samples t-test for Quiz 4

\begin{tabular}{ccccccc}
\hline Quiz 4 & Group & $\mathrm{n}$ & $\mathrm{M}$ & $\mathrm{SD}$ & $\mathrm{t}$ & $\mathrm{p}$ \\
\hline Productive & Control & 28 & 37.6786 & 9.37709 & -3.257 & .002 \\
Vocabulary & Experimental & 27 & 44.8148 & 6.57523 & -3.277 & .002 \\
Receptive & Control & 28 & 42.3214 & 10.04454 & -2.058 & .045 \\
Vocabulary & Experimental & 27 & 46.8519 & 5.57262 & -2.078 & .044 \\
Grade average & Control & 28 & 80.000 & 16.88743 & -3.110 & .003 \\
& Experimental & 27 & 91.667 & 9.90338 & -3.139 & .003 \\
\hline
\end{tabular}

The data in table 7 show a statistically significant difference between the control and the experimental group in terms of both productive and receptive vocabulary and the average grade in the fourth quiz $(\mathrm{p}<.05)$. As seen in table 6 , the experimental group outdid the control group in both productive and receptive vocabulary and received a higher average grade in the fourth quiz.

The findings that were obtained from the open-ended questionnaires are presented in the tables below. 
Table 8. The aspects of the flipped classroom students favored

\begin{tabular}{ll}
\hline Codes and themes & $\mathbf{n}$ \\
\hline Learning at one's own pace & 8 \\
Learning is consolidated in the classroom & 6 \\
Learning is easy & 6 \\
Learning is long-lasting & 5 \\
Having more time for activities in class & 5 \\
Advance student preparation & 4 \\
Learning is fun & 4 \\
\hline
\end{tabular}

The first question was answered by 25 students out of 26 . As can be seen from table 8 , the most reported advantage of the flipped classroom was learning at one's own pace $(n=8)$. They wrote that they were able to start and stop the videos at any point and watch the videos repeatedly. Six students thought that acquisition of new words was consolidated in the classroom. It was also reported that learning vocabulary was easier with the videos $(n=6)$. For five students, learning became more long-lasting than before. It also allowed more time for practice in the classroom $(n=5)$. According to 4 students, it was good to come to class prepared. The comments of some of the students are as follows:

"I can watch the videos over and over."

"I can pause the videos if I need a break."

"Now, we have more time for more enjoyable activities in class."

"I learn things more easily and faster than before."

"Our learning is consolidated in class and it becomes long-lasting."

Table 9. The aspects of the flipped classroom students disliked

\begin{tabular}{ll}
\hline Codes and themes & n \\
\hline None & 12 \\
Not being able to ask questions immediately & 7 \\
Not always being able to watch the videos & 6 \\
Watching vocabulary videos is boring & 1 \\
Watching videos before class is a heavy task & 1 \\
\hline
\end{tabular}

Out of 26 students who answered the second question, 12 students wrote that there weren't any aspects of the flipped classroom that they did not like. Seven students thought not being able to ask about confusing points immediately was a disadvantage of video lectures. Not always being able to watch the videoswas a drawback of flipped learning for six students. One student found watching vocabulary videos boring. Another thought it was a heavy task to watch the videos before class. The views of students on this item are as follows:

"We can't ask questions about the subject immediately."

"We get bored when we have to watch video lectures."

"I can't always watch the videos before class." 
Table 10. The influence of the flipped classroom

\begin{tabular}{ll}
\hline Codes and themes & n \\
\hline Improved listening comprehension & 16 \\
Improved speaking performance & 14 \\
Increased participation & 12 \\
Improved writing & 7 \\
None & 4 \\
Improved reading & 3 \\
\hline
\end{tabular}

The third item asked students if the flipped classroom had any influence on their classroom performance and language skills. Sixteen students reported a positive influence of flipped learning on listening comprehension thanks to watching English videos more often than before. Fourteen students thought their speaking skills improved as they learnt the pronunciation of many words from the videos. Twelve students wrote that they participated in class activities more than before thanks to advance preparation. Four students, on the other hand, reported that it had no influence on their classroom performance. The comments of some of the participants are as follows:

"I feel more confident while speaking, because I've learned the pronunciation of a lot of words from the videos."

"The more I watch videos, the better I become at listening comprehension."

"Since it helped me have a better grasp of the subject, my interest and participation increased."

"I perform better because I can use the words correctly."

"I am more active because we have more time for activities in class."

Table 11. Students' preference of the teaching method

\begin{tabular}{ll}
\hline Codes and themes & $\mathrm{n}$ \\
\hline Willing to continue with the flipped method. & 21 \\
Undecided. & 4 \\
Unwilling to continue with the flipped method. & 1 \\
\hline
\end{tabular}

The fourth item asked students if they wanted to carry on with flipped learning. While twenty one students thought it was a good idea to continue with flipped learning, one student disagreed. Four of the participants reported they were undecided about whether to carry on with flipped learning or not.

Table 12. Students' suggestions to improve the flipped method

\begin{tabular}{ll}
\hline Codes and themes & n \\
\hline More variety in the presentation techniques in the videos & 10 \\
None & 5 \\
Watching videos more frequently & 4 \\
Videos on different language areas & 3 \\
\hline
\end{tabular}

The last item asked the participants if they had any suggestions to improve the flipped learning activities. The most reported suggestion was varying the ways in which vocabulary was presented in the videos $(n=10)$. While five of the participants offered no suggestions, four of them suggested having videos more frequently. Three students suggested having similar videos for other language areas such as the grammar. The views on this item are as follows:

"Watching more videos would be more useful." 
"Videos could be made using different elements like animation."

"Videos on grammar points could be interesting and useful,too."

\section{Discussion}

The findings of this study indicated that flipped instruction effectively and significantly promoted thevocabulary development of English learners in a secondary education setting. Students that received flipped instruction performed significantly better in tests of receptive and productive vocabulary knowledge than students that received traditional instruction. This finding is consistent with similar studies in the literature. Other studies also report positive effects of the flipped instruction on student learning and performance (Bergmann \&Sams, 2012; Basal, 2015; Zhang, Li, Jiao, Ma and Guan, 2016; Roth and Suppasetseree, 2016; Alsowat, 2016).

This study also found that students who received flipped vocabulary instruction generally had positive attitudes towards the learning environment and the activities involved in a flipped classroom. The studentsstated that they enjoyed learning from vocabulary videos, which was quick and easy for them. Furthermore, they thought the class activities consolidated their learning and led to long-lasting vocabulary learning. They favored the self-pacing and the advance preparation that the videos provided. They believed they participated in the activities better than before, as they came to class prepared.The studentsalso expressed that they perceived improvements in their performance of alllanguage skills, particularly speaking and listening,as a result of watching videos in English. Similar findings were reported in the literature as to the advantages of flipped learning (Davies, Dean, Ball; 2013; Basal, 2015; Han, 2015). Learning from videos and applying this knowledge collaboratively in the classroom clearly appealed to the students, as the majority suggested watching video lectures more frequently.

Not being able to ask for clarification on confusing points whilewatching the videos was a problem for some students, though. Some of the studentsalso complained about having to watch the videos before class, which they sometimes found hard to do. These problems may stem from Turkish students' insufficient learning autonomy as demonstrated in a number of studies (Koçak, 2003; Büyükyavuz and İnal, 2008; Karabıyık, 2008; Gökdemir; 2010). These studies revealed that most Turkish students are not used to taking responsibility for their learning; instead, they are overly dependent on teachers. As a matter of fact, lack of learner autonomy has been linked to poor achievement and it has been found that autonomous learners are more likely to be successful (Chan, 2001a; Chan et al., 2002; Cotterall, 1995, 1999; Dickinson, 1995; Holec, 1981; Littlewood, 1999). In this respect, the flipped classroom can help develop autonomy by holding students responsible for their own learning. The sooner we begin training our students to learn autonomously, the sooner they become better learners.

The results of the questionnaire also showed that students were satisfied with having more time for hands-on activitiesin class thanks to the flipped classroom. While traditional learning is linear and passive, the flipped learning is dynamic and collaborative. It is possible that students would rather be active in class than listen to vocabulary lectures passively. This is evident in the number of students that prefer to continue with flipped instruction according to the results of our questionnaire.

\section{Conclusions}


Considering the quantitative and the qualitative data in this study, it can be concluded that the flipped classroom has great potential to enhance vocabulary development of learners in a secondary education setting. Since vocabulary holds the key for proficiency in all language skills, it can positively affect the whole language learning process. Thus, more research and publicity are required to introduce this method to English teachers in Turkey.

Using the Internet and technological devices fill a large part of teenagers' lives, so it seems only natural that they learn the same way. After all, instructional methods should suit the changing needs and ways of our learners. Last but not least, educating our students to become autonomous learners and apply knowledge collaboratively prepares them for real life tasks ahead. The flipped classroom can help create such a learning environment for a promising future.

\section{References}

Alsowat, H. (2016). An EFL flipped classroom teaching model: Effects on English language higherorder thinking skills, student engagement and satisfaction. Journal of Education and Practice, 7(9)

Basal, A. (2015). The implementation of a flipped classroom in foreign language teaching. Turkish Online Journal of Distance Education- TOJDE, 16(4)

Baz, E.H. (2016).Attitudes of Turkish EFL student teachers towards technology use. Turkish Online Journal of Educational Technology - TOJET, 15(2)

Bergmann, J., \&Sams, A. (2012). Flip your classroom: Reach every student in every class every day. Alexandria, VA: International Society for Technology in Education.

Buyukyavuz O. \&Inal S. (2008). A descriptive study on Turkish teachers of English regarding their professional needs, efforts for development and avail-able resources. The Asian EFL Journal, 10, 215-234.

Chan, V. (2001a). Learning autonomously: The learners' perspectives. Journal of Further and Higher Education, 25(3), 285-300.

Chan, V. (2001b). Readiness for learner autonomy: What do our learners tell us? Teaching in Higher Education, 6(4), 505-518.

Chan, V., Spratt, M., \& Humphreys, G. (2002). Autonomous language learning: Hong Kong tertiary students' attitudes and behaviours. Evaluation and Research in Education, 16(1), 1-18.

Cotterall, S. (1995). Readiness for autonomy: Investigating learner beliefs. System, 23(2), 195-205.

Cotterall, S. (1999). Key variables in language learning: What do learners believe about them? System, 27(4), 493-513.

Craik, F. I. M., \&Tulving, E. (1975). Depth of processing and the retention of words in episodic memory. Journal of Experimental Psychology: General, 104, 268-294.

Davies, R. S., Dean, D. L., \& Ball, N. (2013). Flipping the classroom and instructionaltechnology integration in a college-level information systems spreadsheetcourse. Educational Technology Research and Development, 61(4), 563-580.

Dickinson, L. (1995). Autonomy and motivation a literature review. System, 23(2), 165-174.

Gairns, R. \& Redman, S. (1986).Working with words. Cambridge: CUP.

Han, Y. J. (2015). Successfully flipping the ESL classroom for learner autonomy, NYS TESOL Journal, 2(1). 
Holec, H., (1981). Autonomy and foreign language learning. Oxford: Pergamon. (Firstpublished 1979, Strasbourg: Council of Europe)

Hung, H.T. (2014). Flipping the classroom for English language learners to foster active learning, Computer Assisted Language Learning, 28(1), 81-96.

Karabiyık, A. (2008). The relationship between culture of learning and Turkish university preparatory students' readiness for learner autonomy. (Unpublished master's thesis). Bilkent University, Ankara, Turkey.

Kocak, A. (2003). A study on learners' readiness for autonomous learning of English as a foreign language. (Unpublished master's thesis) Middle East Technical University, Ankara, Turkey.

Lewis. M. (1993). The lexical approach. Hove: Language teaching Publications.

Liu, J. (2009). A survey of EFL learners' attitudes toward information and communication technologies. EnglishLanguage Teaching, 2(4), 101-106.

Littlewood, W. (2001). Do Asian students really want to listen and obey? ELT Journal, 54(1), 31-36.

Lynch, M. (2016). Focus on these four areas to create a classroom environment conducive to learning, The Edvocate. Retrieved from http://www.theedadvocate.org/focus-four-areas-create-classroomenvironment-conducive-learning/

Malvern, D., Richards, B., Meara, P., \& Milton, J. (2008). Introduction: special issue on knowledge and use ofthe lexicon in French as a second language. French Language Studies, 18, 269-276.

Mehring, J. (2016). Present research on the flipped classroom and potential tools for the EFL classroom, Computer Assisted Language Learning, 33(1), 1-10.

Milton, J. (2013). Measuring the contribution of vocabulary knowledge to proficiency in the four skills. In C. Bardel, C. Lindqvist, \& B, Laufer(Eds). L2 Vocabulary acquisition, knowledge and use: New perspectives on assessment and corpus analysis, European Second Language Association, pp. 57-78.

Murdoch, J. \&Williams, A. (2011). Creating an online learning community: Is it possible? Innovative Higher Education, 36(5), 305-315.

Nation, I. S. P. (2001). Learning vocabulary in another language. Cambridge: Cambridge University Press.

Richards, J.C. (2006). Communicative language teaching today. New York: Cambridge University Press.

Roth, C. \&Suppasetseree, S. (2016). Flipped classroom: Can it enhance English listening comprehension for pre-university students in Cambodia? Proceedings of CLaSIC 2016, 255-264

Schmitt, N. (2010). Researching vocabulary. A Vocabulary research manual. Basingstoke: PalgraveMacmillan.

Shahov, V. (2012). Measuring L2 receptive and productive vocabulary knowledge, University of Reading Language Studies Working Papers, 4, 37-45

Wittrock, M.C. (1992). Generative learning processes of the brain. Educational Psychologist, 27 (4), 531-541

Zhang, H., Li, J., Jiao, L., Ma, W. \& Guan, C. (2016). The adjustment and effects of vocabulary teaching strategies in flipped classroom. Creative Education,7, 1966-1973. 


\section{Ters-yüz sınıfın algısal ve üretken kelime öğrenimine etkileri}

\section{$\ddot{O} \mathbf{z}$}

Bu çalışmanın amacı, hem algısal hem de üretken kelime bilgisi açısından ters-yüz sınıfın kelime öğrenimine etkilerini ölçmektir. Bunu yapmak için art sınav yöntemi uygulandı. Çalışmanın katılımcıları 58 lise öğrencisidir. Deney grubu, öğretmen tarafından hazırlanmış videolara çalışarak derse geldikleri 4 haftalık ters-yüz öğretime tabi tutuldu. Alıştırmalar grup çalışması şeklinde sınıfta yapıldı. Kontrol grubuna hedef kelimeler geleneksel yöntemle sınıfta öğretildi. Alıştırmalar ise ev ödevi olarak verildi. Her öğretim sonunda gruplara quiz uygulandı. Sonuçlar SPSS program kullanılarak analiz edildi. Deney grubunun ters-yüz sınıf algıları açık uçlu sorulardan oluşan bir anketle ölçüldü. Çalışmanın sonuçlarına göre ters-yüz sınıfın kelime öğrenimi açısından dil öğrenim sürecine katkısı olduğu söylenebilir.

Anahtar sözcükler: ters-yüz sınıf; algısal kelime; üretken kelime

\section{AUTHOR BIODATA}

Dr. ÖzkanKırmızı completed his B.A. at Hacettepe University, English Language Teaching Department. He alsofinished his M.A. and doctoral degree from the same department at Hacettepe University. He started working asan "assistant professors" in 2012 and became an Assoc. Prof. in March, 2018. Currently, he is working at KarabukUniversity English Language and Literature Department. His interest areas are L2 teacher development, preservice EFL teacher education, and intercultural communicative competence.

Funda KÖMEÇ was born in Ankara. She received her MA degree in English Language and Literature from Karabük University in 2018. She works as an English teacher at a state high school in Karabük. Her research interests include technology enhanced language learning, development of language skills, and autonomous learning. 